\title{
REVIEWS
}

\section{APPLICATION OF HIGH-PRESSURE PROCESSING FOR SAFETY AND SHELF-LIFE QUALITY OF MEAT - A REVIEW}

\author{
Sanita Sazonova*, Ruta Galoburda, Ilze Gramatina \\ Department of Food Technology, Faculty of Food Technology, Latvia University of Agriculture, Riga street 22, Jelgava, Latvia, \\ e-mail: sanita.sazonova@llu.lv
}

\begin{abstract}
In recent years, there has been growing consumer demand for the minimally processed, free from chemical additives and healthier meat, which has led to the development of alternative technologies to conventional heat treatments. High pressure processing (HPP) is known as a non-thermal intervention for extending the shelf-life and safety of meat. The aim of this review is to analyse the scientific literature about the changes that occur in meat after application of the HPP.

The HPP is effective in controlling microflora in meat and meat products at 400-600 MPa, thus extending its shelf-life. The inactivation efficiency of the HPP mainly depends on treatment conditions, type of microorganisms, and food matrix characteristics. However, the HPP may negatively affect meat quality attributes, such as colour and texture. Meat processed at pressures above $300 \mathrm{MPa}$ has cooked like appearance, which might be unacceptable to consumers. The HPP increases meat toughness, but when processed at relatively low pressures (100-250 MPa) in combination with increased temperature (above $60{ }^{\circ} \mathrm{C}$ ) meat becomes more tender. Pre-rigor muscle treatment proved meat tenderization after cooking. It has been revealed that the HPP above $400 \mathrm{MPa}$ makes the polyunsaturated fatty acids more susceptible to oxidation, which may have negative effect on stored meat flavour. Another factor affecting meat flavour may be activity of enzymes. Processing of meat at $150 \mathrm{MPa}$ decreases cook loss and increases water holding capacity. Several researchers suggest using multi hurdle approach (use of antimicrobials and antioxidants) for processing at lower pressures reducing negative effect on quality characteristics.
\end{abstract}

Keywords: microbial inactivation, meat colour, meat texture, shelf-life.

\section{Introduction}

Nowadays consumers more often pay attention to nutrition information and list of ingredients on labels of food packaging and there is a high demand for less salty, less acidified, less chemical preserved, minimally processed, but at the same time very safe products with high nutritional value, and extended shelf life (Campus, 2010; Hygreeva, Pandey, 2016). By applying proper technological treatment it is possible to eliminate a number of additives used for product preservation maintaining nutritional and organoleptic properties of the food similar or identical to the raw or fresh form (Heinz, Buckow, 2010). During classical thermal treatments natural flavour and quality of the food product are affected, therefore the necessity for effective non-thermal treatment emerges. Some promising non-thermal technologies are applied at industrial level for decontamination of meat products, gamma, electron and X-ray irradiation, high hydrostatic pressure, natural antimicrobials, active packaging, and radiofrequency, to name just some of them (Campus, 2010). These technologies have high acceptability for use in food processing as they preserve natural appearance of treated food product while eliminating the pathogens and spoilage microoorganisms, moreover, they are energy saving and environmentally friendly what is not of less importance for producers (Aymerich et al., 2008). High pressure processing (HPP), also known as cold pasteurization of food is a non-thermal technology and at present moment is one of the most successful alternatives for thermal food preservation technologies adopted by the food industry and commonly used for treating meat and meat products as approximately $29 \%$ of the industrial HP equipment is used in the meat industry (Aymerich et al., 2008; Campus, 2010). As a commercially viable technology for the pasteurization it is used for both liquid and solid products of diverse origin such as meat, seafood, beverages, dairy, fruits, and vegetables (Tonello, 2011). By using HPP, both spoilage and pathogenic microorganisms in meat are inactivated, shelf life is extended, while the characteristics and the quality of meat and meat products are maintained (Balasubramaniam, Farkas, 2008; Jofré, Serra, 2016). High pressure might be transferred instantly throughout a flexible package regardless of size, shape, or composition of the food. HPP offers the possibility to have mildly processed, wholesome, fresh-tasting product with minimal to no preservatives to satisfy health conscious consumers (Jofré, Serra, 2016). Furthermore, HPP has big potential for the innovative development of new products with relatively low energy consumption as well as can be combined with existing trends in the food sector to boost the development of the food industry (Hugas et al., 2002).

The present review covers high pressure processing effects on quality attributes of meat regarding its safety and shelf-life.

\section{General principles of high pressure application on foods}

Pressure is an important thermodynamic parameter with unique effects on biological systems (Aertsen et al., 2009). During HPP, the food is placed in the pressure vessel and submitted to pressures from 100 to $900 \mathrm{MPa}$. The pressure applied is isostatically transmitted inside the pressure vessel. The technology is based on the Pascal's law and Le Chatellier principle, so high pressure is transmitted in a uniform 
and instantaneous manner and the product is compressed, independently of its size and geometry, or its constituents (Balasubramaniam et al., 2016). The temperature of the food subjected to high-pressure treatment is usually increased by approximately $3{ }^{\circ} \mathrm{C}$ per each $100 \mathrm{MPa}$ increase when applied at ambient temperatures $\left(\sim 25^{\circ} \mathrm{C}\right)$ (Aymerich et al., 2008). This temperature increase is known as "heat of compression" which is generated within the material due to compressive work against intermolecular forces. If the food contains a significant amount of fat the temperature increase can reach up to $9{ }^{\circ} \mathrm{C}$ per $100 \mathrm{MPa}$ increase (Rasanayagam et al., 2003). The efficacy of the treatment depends on the achieved pressure, the treatment temperature and the exposure time. In industrial applications of high pressure food processing pressures of up to $800 \mathrm{MPa}$ may be applied.

High pressure effects on foods are highly dependent on the primary effects of pressure and temperature on the relevant thermodynamic and transport properties of food systems such as density, viscosity, thermal conductivity, compressibility, heat capacity, diffusivity, phase transition properties (e.g., melting point), and solubility. Pressure drastically influences the values of those properties. Biochemical transformations under high pressure can be irreversible or reversible, depending on involved substances, environmental conditions, and the combination of pressure, temperature, and exposure time (Buckow et al., 2013).

\section{Influence of high pressure on meat}

HPP affects quality parameters of fresh meat and thus typical characteristic associated with fresh meat like texture and especially colour can be remarkably modified (Bajovic et al., 2012; Hughes et al., 2014). As a consequence of the le Chatelier principle, during high pressure, depending on its level, occurs degradation or modification of the meat proteins, inactivation of enzymes, changes in the substrate-enzyme interactions and in carbohydrates and fats (Butz, Tauscher, 2002). However, the nutritional value, vitamins and the majority of small substances responsible for the flavours of the products are preserved (Schindler et al., 2010).

\subsection{Effect of HPP on meat proteins}

High pressure application to muscle proteins alters their properties as they undergo physiochemical changes such as denaturation, dissociation, solubilisation, aggregation, and gelation. These factors strongly depend on pressure level, temperature, $\mathrm{pH}$ and ionic strength (Jofré, Serra, 2016). In meat, the most significant effect of pressure is detected for sarcoplasmic and myofibrillar proteins. Sarcoplasmic meat proteins (mainly enzymes and heme pigments) are very susceptible to denaturation when undergo HPP at pressure level above $200 \mathrm{MPa}$ during which water holding capacity and colour of the meat changes (Marcos et al., 2010). Myofibrillar proteins, are related to the meat structure and are unfolded if pressure is
$300 \mathrm{MPa}$ and higher. As a result, occurs denaturation, agglomeration, and gel formation (Sun, Holley, 2010; Chan et al., 2011; Grossi et al., 2016). Thus, apart from its food preservation capabilities, HPP also has potential to manipulate the texture of foods and, hence, has been suggested as a physical and additive-free process to tenderize and soften meat and meat products. Such structural modifications of meat proteins also are used by the food industry in new product development (Sun, Holley, 2010; Sikes et al., 2010; Buckow et al., 2013).

\subsection{Effect of HPP on the colour of meat}

Colour is one of the most important quality attributes for the consumer when purchasing meat (Cheftel, Culioli, 1997). Meat colour is determined by the amount and chemical state of the hemoproteins present as well as by the structure of the meat. Studies indicate that HPP provokes drastic changes in fresh meat colour, while the changes in cured meat products are acceptable and depending on the water content and water activity (aw) value (Bajovic et al., 2012; Ferrini et al., 2012). Colour changes due to oxidation of ferrous myoglobin into ferric metmyoglobin. To reach microbial inactivation in meat, usually pressure above $400 \mathrm{MPa}$ is applied, as the result of such pressure increase, meat discoloration occurs due to the protein denaturation (Wackerbarth et al., 2009) It has often been reported that even by application of pressure above $200 \mathrm{MPa}$ drastically changes the appearance of red meat within a few minutes of treatment at low temperatures (Tintchev et al., 2010; Buckow, 2013). Most studies report increase of lightness $\left(\mathrm{L}^{*}\right)$ in the pressure range 200-350 $\mathrm{MPa}$ turning red colour of meat into a paler pink, redness $\left(\mathrm{a}^{*}\right)$ is observed to decrease in values at 400-500 MPa, resulting in a greybrown meat with a cooked-like appearance, however, this is the more variable parameter and dependent on experimental design (i.e., type of meat, minced or whole muscle, and HPP conditions), and yellowness $\left(b^{*}\right)$ either increases or is not affected (Jung et al., 2003; Morales et al., 2008; Tintchev et al., 2010; Souza et al., 2011; Ferrini et al., 2012; Jofré, Serra, 2016). The changes of colour of high pressure treated pork meat at 200 to $800 \mathrm{MPa}$ at 5 and $20{ }^{\circ} \mathrm{C}$ for $10 \mathrm{~min}$ was shown to depend mostly on pressure level and to a lesser degree on applied temperature (Bak et al., 2012).

\subsection{Effect of HPP on lipid oxidation of meat}

Pressure levels between 300 and $600 \mathrm{MPa}$ are critical for inducing lipid oxidation in fresh pork, beef and poultry meat as well as in meat products, which may lead to significant changes in the lipid content and fatty acid composition of phospholipids and free fatty acids (Marcos, 2010; Fuentes et al., 2010; Huang et al., 2015). HPP induced lipid oxidation mechanisms are not fully understood, it has been suggested that HPP can promote lipid oxidation as it increases accessibility for iron from hemoproteins and disrupts membranes (Bajovic et al., 2012). Oxidation is one of the most important factors in the non-microbial 
degradation of meat (Guyon et al., 2016). Lipid oxidation is not usually evident immediately after HPP but may become evident during chilled storage (Tume et al., 2010). Such oxidation affects quality through flavour deterioration (rancidity), colour changes, loss of nutritive value, and alterations of textural and functional properties through associated protein denaturation (Fuentes et al., 2010; Buckow, 2013). There are suggested possibilities to inhibit the lipid oxidation by limiting oxygen availability in the packaging, use of antioxidant active packaging or use of different antioxidants derived from natural by-products and their combination (Mariutti et al., 2008; Bolumar et al., 2011; Alves et al., 2012).

\section{Microbiological Aspects}

Meat is nutritionally rich product and serves as suitable media for growth of meat spoilage microorganisms and common food-borne pathogens, therefore, it is of high importance to choose and apply proper preservation technologies (Aymerich et al., 2008). HPP as a non-thermal food preservation technique has proved to be effective in inactivating variety of food-borne pathogens and spoilage-causing organisms (vegetative cells, yeasts, moulds, and viruses) (Considine et al., 2008; Tonello, 2011).

Inactivation of microorganisms by HPP is a combination of factors affecting physical properties of cell membrane, proteins and enzymes, and genetic mechanisms. Cell membrane is known to be the primary site of a pressure damage with consequent changes in the permeability of the cells, transport systems, loss of the osmotic responsiveness and incapacity to keep $\Delta \mathrm{pH}$, as well as changes in the rate of specific physiological functions that cause irreversible or lethal damage on bacteria cells (Ritz et al., 2001; Molina-Guitierrez et al., 2002). Surface dwelling microorganisms live at atmospheric pressure $(0.1 \mathrm{MPa})$ and progressively stop growing at 40-50 MPa (Simonato et al., 2006). For the majority of microorganisms, the highest pressure tolerance is found between 20 and $30{ }^{\circ} \mathrm{C}$. It is possible to decrease the stability of these microorganisms if the lower temperatures are applied during high pressure treatments (Buckow, Heinz, 2008). However, there are an increasing number of mesophilic microorganisms with achieved significant improvement of growth under high pressure or resistance to high pressure directed by evolution (Hauben et al., 1997; Karatzas, Bennik, 2002; Pavlovic et al., 2008; Aertsen et al., 2009).

Ability to resist pressure treatment varies considerably among different microorganisms' type, form (vegetative cells or spores, Gram-positive or Gram negative), genus, species, and strain. With some exceptions, the pressure resistance of bacteria depends on the morphology and size of the cells, as it is observed the most sensitive bacteria are rod-shaped whereas the spherical-shaped are more resistant (Ludwig, Schreck, 1997). Gram-positive bacteria are generally more resistant than Gram-negative bacteria, and spores are more resistant than vegetative cells to pressure treatment (Patterson, 2005; Jofré et al., 2010). Strains within the same species can have wide range of sensitivity against physical stresses caused by HPP (Liu et al., 2012), therefore, identification of target microorganism is crucial for the process validation studies. Moreover, higher pressure resistance is reported for microbial cells in stationary growth phase comparing to those at exponential conditions (Manas, Mackey, 2004; Manas, Pagan, 2005).

The response to HPP of microorganisms in meat and meat products is variable and depends on process parameters such as pressure, temperature, and processing time as well as on product parameters such as $\mathrm{pH}$, aw, salt content, and the presence of antimicrobials (Töpfl, Heinz, 2009; Rendueles et al., 2011; Bajovic et al., 2012). Rich nutrient media such as meat reinforce the resistance of the microorganisms to HPP due to the protective effect of carbohydrates, proteins and lipids in meat (Simpson, Gilmour, 1997). A great number of studies have shown HHP efficiency to control microorganisms in meat and meat products (Hugas et al., 2002; Aymerich et al., 2005; Lindsay et al., 2006; Morales et al., 2006; Rubio et al., 2007; Campus, 2010; Bajovic et al., 2012 Jofré, Serra, 2016). Pressure levels applied for the pasteurization of meats and meat products, range in an area of 400-600 MPa for a short processing time, from seconds to several minutes at room temperature. Eukaryote vegetative forms from fungi and moulds are inactivated with pressure of 200-300 MPa while their spores need a $400 \mathrm{MPa}$ treatment. The majority of pressure-sensitive bacteria begin to lose viability at approximately $180 \mathrm{MPa}$. In a pressure range of about 200-400 MPa occur irreversible changes such as cell leakage leading to cell death (Lado, Yousef, 2002). These treatments lead in most cases to an inactivation of $>4 \mathrm{log}$ units for the most common vegetative pathogenic and spoilage microorganisms resulting in an increased shelf-life and improved safety (Rubio et al., 2007; Bajovic et al., 2012).

The cell death increases with pressure but does not follow a first order kinetics and a tail of inactivation is sometimes present (Garriga et al., 2002). These resistant or sublethally injured cells could be able to grow during storage (Bozoglu et al., 2004), therefore, HPP cannot be used as single technology for meat preserving as products still require refrigerated storage during subsequent handling and distribution (Carlez et al., 1994; Chen, Hoover, 2003).

\section{Hurdles technology}

Hurdles technology describes application of two or more preservation techniques combined to establish a series of preservative factors (hurdles), as the result, microbial stability, sensory quality, and nutritional properties of food products improve (Leistner, 2000; Zhou et al., 2010).

However, more than 60 potential hurdles for foods, which improve the stability and/or quality of the 
products, have been described, and the list of possible hurdles for food preservation is by no means complete (Leistner, Gorris, 1995; Zhou et al., 2010; Rodriguez et al., 2016). Combination of hurdles together with HPP increases the antimicrobial effect of low pressure processes and minimize the unwanted changes induced by ultra-high pressures (above $400 \mathrm{MPa}$ ) (Bajovic et al., 2012). As hurdles may be used temperature (high or low), water activity, redox potential, vegetable extracts, organic acids, carbon dioxide, bacteriocins, osmotic dehydration, pulsed electric field, ohmic heating, and others. The combination of hurdles may be positive if the effect of preservation factors summarizes. In a highly effective case may be observed synergistic effect when both preservation factors together enhance the effect of each factor. For meat and meat products synergistic effects with HPP have been described with antimicrobials, low $\mathrm{pH}$, carbon dioxide, vacuum packaging and chilled storage (Garriga, Aymerich, 2009; Jofré et al., 2010). Moreover, additional hurdles or processes are useful to avoid the recovery of injured cells (Liu et al., 2012).

Bacterial spores may be extremely resistant if pressure treatment is applied at ambient temperatures, therefore a different approach to the method is required. Application of very high pressure $(1 \mathrm{GPa})$ or very long holding times (from $30 \mathrm{~min}$ to hours) is effective but not suitable for industrial applications due to high energy consumption. In such cases it is necessary to apply pressure in combination with high temperature. This method is called pressure assisted thermal sterilization (PATS) and inactivates even the most heat-resistant spores. By increasing temperature during HPP lethality of total microorganisms enhances, however, it leads to a higher degree of protein denaturation and, as a result, it affects the fresh-like characteristics of the meat (Balasubramaniam et al., 2016).

\section{Packaging}

During storage time packaging protects products against deteriorative effects such as discolouration, offflavour and off-odour development, nutrient loss, texture changes, pathogenicity and other factors (Zhou et al., 2010). High pressure treatment commonly is combined with vacuum packaging. If the meat is subjected to HPP after packaging it is possible to reduce secondary contamination simultaneously maintaining the freshness of the meat and extending its shelf life (Huang et al., 2017). The lack of $\mathrm{O}_{2}$ in packages may minimise the oxidative deteriorative reactions, and reduce aerobic bacteria growth. Low $\mathrm{O}_{2}$ vacuum packages for retail meat cuts are usually vacuum skin packaging systems with vacuum sealing barrier films that are heat shrunk to conform to the shape of the product (Belcher, 2006).

\section{Conclusions}

HPP is an alternative technology to preserve foods with reduced thermal requirement and commonly is used for meat and various meat products treatment. As the result, the nutritional value, of the products is preserved and shelf-life extended without the use of preservatives or additives. However, depending on the pressure level applied, HPP affects quality parameters like texture and colour typically associated with fresh meat - the meat becomes more gel-structured and paler. HPP is an effective method to enable the control of pathogenic and spoilage microorganisms in meat products. The response to HPP of microorganisms in meat and meat products is variable and depends on process parameters and on product parameters. Commercially applied pressure levels range in an area of $400-600 \mathrm{MPa}$ with short processing times at ambient temperatures resulting in inactivated majority of pathogenic and spoilage microorganisms. If additional hurdles technologies are applied in combination with HPP it is possible to increase shelf-life and improve safety of the meat. Lately HPP gains its popularity on commercial scale as a lowtemperature treatment, environmentally friendly and waste-free technology.

\section{References}

1. Aertsen A., Meersman F., Hendrickx M. E. G., Vogel R. F., Michiels C. W. (2009) Biotechnology under high pressure: applications and implications. Trends in Biotechnology, Vol. 27 (7), p. 434-441.

2. Alves A. B., Bragagnolo N., da Silva M. G., Skibsted L. H., Orlien V. (2012) Antioxidant protection of high-pressure processed minced chicken meat by industrial tomato products. Food and Bioproducts Processing, Vol. 90(3), p. 499-505.

3. Aymerich M. T., Jofre A., Garriga M., Hugas M. (2005). Inhibition of Listeria monocytogenes and Salmonella by natural antimicrobials and high hydrostatic pressure in sliced cooked ham. Journal of Food Protection, Vol. 68, p. 173-177.

4. Aymerich M. T., Picouet P.A., Monfort J.M. (2008) Decontamination technologies for meat products. Meat Science, Vol. 78, p. 114-129.

5. Bak K. H., Lindah G., Karlsson A. H., Orlien V. (2012) Effect of high pressure, temperature, and storage on the colour of porcine longissimus dorsi. Meat Science, Vol. 92, p. 374-381.

6. Bajovic B., Bolumar T., Heinz V. (2012) Quality considerations with high pressure processing of fresh and value added meat products. Meat Science, Vol. 92, p. 280-289.

7. Balasubramaniam V. M., Farkas D. (2008) High pressure processing. Food Science and Technology International, Vol. 14, p. 413-418.

8. Balasubramaniam V.M., Barbosa-Cánovas G. V. Lelieveld H. L. M. (2016) High Pressure Processing of Food. High Pressure Processing of Food - Principles, Technology and Applications. New York: Springer Science+Business Media. 758 p.

9. Belcher J. N. (2006) Industrial packaging developments for the global meat market. Meat Science, Vol. 74, p. $143-148$.

10. Bolumar T., Andersen M. L., Orlien V. (2011) Antioxidant active packaging for chicken meat processed by high pressure treatment. Food Chemistry, Vol. 129 (4), p. 1406-1412. 
11. Bozoglu F., Alpas H., Kaletunç G. (2004) Injury recovery of foodborne pathogens in high hydrostatic pressure treated milk during storage. FEMS Immunology \& Medical Microbiology, Vol. 40 (3), p. 243-247.

12. Buckow R., Heinz V. (2008) High pressure processing A database of kinetic information. Chemie Ingenieur Technik, Vol. 80 (8), p. 1081-1095.

13. Buckow R., Sikes A., Tume R. (2013) Effect of High Pressure on Physicochemical Properties of Meat. Food Science and Nutrition, Vol. 53, p. 770-786.

14. Butz P., Tauscher B. (2002) Emerging technologies: Chemical aspects. Food Research International, Vol. 35, p. 279-284.

15. Campus M. (2010) High Pressure Processing of Meat, Meat Products and Seafood. Food Engineering, No. 2, p. 256-273.

16. Carlez A., Rosec J. P., Richard N., Cheftel J. C. (1994) Bacterial growth during chilled storage of pressuretreated minced meat. Food Science and Technology, Vol. 27, p. 48-54.

17. Chan J. T. Y., Omana D. A., Betti M. (2011) Application of high pressure processing to improve the functional properties of pale, soft, and exudative (PSE)-like turkey meat. Innovative Food Science and Emerging Technologies, Vol. 12 (3), p. 216-225.

18. Cheftel J. C., Culioli J. (1997) Effects of high pressure on meat: A review. Meat Science, Vol. 46 (3), p. 211-236.

19. Chen H., Hoover D. G. (2003) Bacteriocins and their food applications. Food Science and Food Safety, Vol. 2, p. $81-100$.

20. Considine K. M., Kelly A. L., Fitzgerald G. F., Hill C., Sleator R. D. (2008) High-pressure processing - effects on microbial food safety and food quality. FEMS Microbiology Letters, No. 281, p. 1-9.

21. Ferrini G., Comaposada J., Arnau J., Gou P. (2012) Colour modification in a cured meat model dried by Quick-Dry-Slice process and high pressure processed as a function of $\mathrm{NaCl}, \mathrm{KCl}, \mathrm{K}$-lactate and water contents. Innovative Food Science \& Emerging Technologies, Vol. 13, p. 69-74.

22. Fuentes V., Ventanas J., Morcuende D., Estévez M., Ventanas S. (2010) Lipid and protein oxidation and sensory properties of vacuum packaged dry-cured ham subjected to high hydrostatic pressure. Meat Science, Vol. 85 (3), p. 506-514.

23. Garriga M., Aymerich M. T., Costa S., Monfort J. M., Hugas M. (2002) Bactericidal synergism through bacteriocins and high pressure in a meat model system during storage. Food Microbiology, Vol. 19, p. 509-518.

24. Garriga M., Aymerich T. (2009) Advanced decontamination technologies: High hydrostatic pressure on meat products. In: Safety of meat and processed meat. Toldrá F. (ed). New York: Springer, p. 183-208.

25. Grossi A., Olsen K., Bolumar T., Rinnan Å., Øgendal L. H., Orlien V. (2016) The effect of high pressure on the functional properties of pork myofibrillar proteins. Food Chemistry, Vol. 196, p. 1005-1015.

26. Guyon C., Meynier A., de Lamballerie M. (2016) Protein and lipid oxidation in meat: a review with emphasis on high-pressure treatments, Trends in Food Science \& Technology, Vol. 50, p. 131-143.

27. Hauben K.J., Bartlett D. H., Soontjens C. C., Cornelis K., Wuytack E. Y., Michiels C. W. (1997) Escherichia coli mutants resistant to inactivation by high hydrostatic pressure. Applied and Environmental Microbiology, Vol. 63, p. 945-950.
28. Heinz V., Buckow R. (2010) Food preservation by high pressure. Journal of Consumer Protection and Food Safety, Vol. 5, p. 73-81.

29. Huang H. W., Wu S. J., Lu J. K., Shyu Y. T., Wang C. Y. (2017) Current status and future trends of high-pressure processing in food industry. Food Control, Vol. 72 (12), p. 1-8.

30. Huang Y., Gan Y., Li F., Yan C., Li H., Feng Q. (2015) Effects of high pressure in combination with thermal treatment on lipid hydrolysis and oxidation in pork. $L W T$ Food Science and Technology, Vol. 63, p. 136-143.

31. Hugas M., Garriga M., Monfort J. M. (2002) New mild technologies in meat processing: High pressure as a model technology. Meat Science, Vol. 62, p. 359-371.

32. Hughes J. M., Oiseth S. K., Purslow P. P., Warner R. D. (2014) A structural approach to understanding the interactions between colour, waterholding capacity and tenderness. Meat Science, Vol. 98 (3), p. 520-532.

33. Hygreeva D., Pandey M. C. (2016) Novel approaches in improving the quality and safety aspects of processed meat products through high pressure processing technology - A review. Trends in Food Science \& Technology, Vol. 54, p. 175-185.

34. Jofré A., Serra X. (2016) Processing of Meat Products Utilizing High Pressure. In: High Pressure Processing of Food. Balasubramaniam V.M. (ed.). New York: Springer Science+Business Media, p. 591-623.

35. Jofré A., Aymerich T., Bover-Cid S., Garriga M. (2010) Inactivation and recovery of Listeria monocytogenes, Salmonella enterica and Staphylococcus aureus after high hydrostatic pressure treatments up to $900 \mathrm{MPa}$. International Microbiology, Vol. 13 (4), p. 497-503.

36. Jung S., Ghoul M., De Lamballerie-Anton M. (2003) Influence of high pressure on the colour and microbial quality of beef meat. LWT - Food Science and Technology, Vol. 36 (6), p. 625-631.

37. Karatzas K.A., Bennik M.H. (2002) Characterization of a Listeria monocytogenes Scott A isolate with high tolerance towards high hydrostatic pressure. Applied and Environmental Microbiology, Vol. 68, p. 3183-3189.

38. Lado B.H., Yousef A.E. (2002) Alternative foodpreservation technologies: efficiency and mechanisms. Microbes and Infection, Vol. 4, p. 433-440.

39. Leistner L., Gorris L. G. M. (1995) Food preservation by hurdle technology. Trends in Food Science \& Technology, Vol. 6, p. 41-46.

40. Leistner L. (2000) Basic aspects of food preservation by hurdle technology. International Journal of Food Microbiology, Vol. 55, p. 181-186.

41. Lindsay D. S., Collins M. V., Holliman D., Flick G. J., Dubey J. P. (2006) Effects of high-pressure processing on Toxoplasma gondii tissue cysts in ground pork. Journal of Parasitology, Vol. 92, p. 195-196.

42. Liu Y., Betti M., Gänzle M. G. (2012) High pressure inactivation of Escherichia coli, Campylobacter jejuni, and spoilage microbiota on poultry meat. Journal of Food Protection, Vol. 75 (3), p. 497-503.

43. Ludwig H., Schreck C. (1997) The inactivation of vegetative bacteria by pressure. In: High pressure research in the biosciences and biotechnology. Heremans K. (ed). Leuven: Leuven University Press, p. 221-224.

44. Manas P., Mackey B. M. (2004) Morphological and physiological changes induced by high hidrostatic pressure in exponential and stationary phase cells of Escherichia coli: relationship with cell death. Applied 
and Environmental Microbiology, Vol. 70 (3), p. $1545-1554$.

45. Manas P., Pagan R. (2005) Microbial inactivation by new technologies of food preservation. Journal of Applied Microbiology, Vol. 98, p. 1387-1399.

46. Mariutti L. R., Orlien V., Bragagnolo N., Skibsted L.H. (2008) Effect of sage and garlic on lipid oxidation in high pressure processed chicken meat. European Food Research and Technology, Vol. 227, p. 334-337.

47. Marcos B., Kerry J. P., Mullen A. M. (2010) High pressure induced changes on sarcoplasmic protein fraction and quality indicators. Meat Science, Vol. 85, p. $115-120$.

48. Molina-Guitierrez A., Stippl V., Delgado A., Ganzle M.G., Vogel R. (2002) In situ determination of the intercellular $\mathrm{pH}$ of Lactococcus lactis and Lactobacillus plantarum during pressure treatment. Applied and Environmental Microbiology, Vol. 68, No. 4, p. 399-406.

49. Morales P., Calzada J., Nunez M. (2006) Effect of highpressure treatment on the survival of Listeria monocytogenes Scott A in sliced vacuum-packaged iberian and serrano cured hams. Journal of Food Protection, Vol. 69, p. 2539-2543.

50. Morales P., Calzada J., Ávila M. (2008) Inactivation of Escherichia coli 0157: H7 in ground beef by single-cycle and multiple-cycle high-pressure treatments. Journal of Food Protection, Vol. 71, p. 811-815.

51. Patterson M. F. (2005) Microbiology of pressure-treated foods. Journal of Applied Microbiology, Vol. 98, p. $1400-1409$.

52. Pavlovic M., Hormann S., Vogel R.F., Ehrmann M. A. (2008) Characterisation of a piezotolerant mutant of Lactobacillus sanfranciscensis. Zeitschrift für Naturforschung, Vol. 63, p. 791-797.

53. Rasanayagam V., Balasubramaniam V. M., Ting E., Sizer C. E., Bush C., Anderson C. (2003) Compression heating of selected fatty food materials during high-pressure processing. Journal of Food Science, Vol. 68 (1), p. $254-259$.

54. Rendueles E., Omer M. K., Alvseike O., Alonso-Calleja C., Capita R., Prieto M. (2011) Microbiological food safety assessment of high hydrostatic pressure processing: A review. LWT - Food Science and Technology, Vol. 44 (5), p. 1251-1260.

55. Ritz M., Tholozan J. L., Federighi M., Pilet M. F. (2001) Morphological and physiological characterization of Listeria monocytogenes subjected to high hydrostatic pressure. Applied and Environmental Microbiology, Vol. 67, p. 2240-2247.

56. Rodrigues I., Trindade M.A., Caramit F.R., Candoğan K., Pokhrel P.R., Barbosa-Cánovas G.V. (2016) Effect of high pressure processing on physicochemical and microbiological properties of marinated beef with reduced sodium content. Innovative Food Science and Emerging Technologies, Vol. 38, p. 328-333
57. Rubio B., Martinez B., Garcia-Gachan M. D., Rovira J., Jaime I. (2007) Effect of high pressure preservation on the quality of dry cured beef "Cecina de Leon". Innovative Food Science and Emerging Technologies, Vol. 8, p. 102-110.

58. Schindler S., Krings U., Berger R. G., Orlien V. (2010) Aroma development in high pressure treated beef and chicken meat compared to raw and heat treated. Meat Science, Vol. 86, p. 317-323.

59. Simonato F., Campanaro S., Lauro F. M., Vezzi A., D’Angelo M., Vitulo N., Valle G., Bartlett D. H. (2006) Piezophilic adaptation: a genomic point of view. Journal of Biotechnology, Vol. 126, p. 11-25.

60. Simpson R., Gilmour A. (1997) The resistance of Listeria monocytogenes to high hydrostatic pressure in foods. Food Microbiology, Vol. 14, p. 567-573.

61. Sikes A. L., Tornberg E., Tume R. K. (2010) A proposed mechanism of tenderising post-rigor beef using high pressure-heat treatment. Meat Science, Vol. 84, p. 390-399.

62. Souza C. M., Boler D. D., Clark D. L., Kutzler L. W., Holmer S. F., Summerfield J. W. (2011) The effects of high pressure processing on pork quality, palatability, and further processed products. Meat Science, Vol. 87, p. 419-427.

63. Sun X. D., Holley R. A. (2010) High pressure effects on the texture of meat and meat products. Journal of Food Science, Vol. 75, p. 17-23.

64. Tonello C. (2011) Case studies on high-pressure processing of foods. In: Nonthermal processing technologies for food. Zhang H. Q., Barbosa-Canovas G. V., Balasubramaniam V. M. B., Dunne C. P., Farkas D. F., Yuan J. T. C. (eds). West Sussex: John Wiley \& Sons Ltd., p. 36-50.

65. Töpfl S., Heinz V. (2009) New options for targeted product modification. Fleischwirtschaft International, Vol. 3, p. 11-13.

66. Tintchev F., Wackerbarth H., Kuhlmann U., Toepfl S., Knorr D., Hildebrandt P., Heinz V. (2010) Molecular effects of high-pressure processing on food studied by resonance Raman. Annals of the New York Academy of Sciences, Vol. 1189, p. 34-42.

67. Tume R. K., Sikes A. L., Smith S. B. (2010) Enriching $M$. sternomandibularis with $\alpha$-tocopherol by dietary means does not protect against the lipid oxidation caused by high-pressure processing. Meat Science, Vol. 84, p. 66-70.

68. Wackerbarth H., Kuhlmann U., Tintchev F, Heinz V., Hildebrandt P. (2009) Structural changes of myoglobin in pressure-treated pork meat probed by resonance Raman spectroscopy. Food Chemistry, Vol. 115, p. 1194-1198.

69. Zhou G.H., Xu X.L., Liu Y. (2010) Preservation technologies for fresh meat - A review. Meat Science, Vol. 86, p. 119-128. 